\title{
EMBODIED ENERGY ASSESSMENT FOR BUILDING MATERIALS
}

\author{
Mithra.P ${ }^{1}$, Linu T Kuriakose ${ }^{2}$, Aravind Unnithan ${ }^{3}$ \\ ${ }^{I} M$ Tech Construction Engineering and Management student, TIST, Arakkunnam, Ernakulam \\ ${ }^{2}$ Asst. Professor, Dept of Civil Engineering, TIST, Arakkunnam, Ernakulam \\ ${ }^{3}$ Asst. Professor, Dept of Civil Engineering, TIST, Arakkunnam, Ernakulam
}

\begin{abstract}
Buildings use various building materials, which have a unique initial embodied energy. Initial embodied energy is the energy required for extraction of raw materials, transportation of these raw materials to the manufacturing unit and the energy required for the manufacturing of the material. Building materials like concrete, cement, clay bricks, etc., which is used in larger quantities in a building, requires large amount of energy during their production process. In this study, a process based approach is used for computing initial embodied energy of common building materials. The initial embodied energy of common and alternative building materials were found out from data collected from various building material manufacturing industries. The study proposes various alternative building materials with low initial embodied energy for a sustainable future.
\end{abstract}

Keywords—embodied energy, process method, data collection.

\section{INTRODUCTION}

Construction industry is fastest growing and major energy consuming sector in India. There is a rapidly growing material consumption in our construction industry. This material consumption is increasing every year. Energy used for manufacturing these materials accounts for about 20$25 \%$ of India's total energy demand. This energy is mainly obtained by the use of non- conventional energy sources, which leads to large amount of $\mathrm{CO}_{2}$ emissions into the atmosphere.

Nowadays most of the residential buildings are built using the conventional buildings like burnt clay bricks, cement, etc. These materials are highly energy intensive. For a sustainable future, low energy materials should be used. Embodied energy of a building material is the energy spent for the production of that material. This includes energy spent for raw material extraction, transportation of these raw materials to the manufacturing unit and the energy spent for manufacture of that building material. The purpose of this study is to compute the embodied energy of some common building materials used in India using process based approach and to propose alternative materials with low embodied energy.

\section{SCOPE OF THE PAPER}

This paper is aimed at assessing the embodied energy of common building materials in India, using process based approach and to propose alternative building materials with low embodied energy for a sustainable future. This paper also provides a general awareness about the embodied energy consumption of some common building materials

\section{MATERIALS AND METHOD}

The study analyzed the energy consumption made by the manufacturing of common and alternative building materials. The materials selected include cement, aggregate, concrete, concrete paving blocks, clay roofing tile, masonry blocks like burned clay bricks, laterite blocks, hollow and solid concrete blocks and mud blocks. Materials like cement, aggregate, concrete, building blocks, etc will be used in larger quantities by a building. Therefore these materials are the main contributors of a building's embodied energy.

For the computation of embodied energy, various building material manufacturing industries were selected. Data for the computation of energy was collected from these industries. For the manufacture of these materials the source of energy includes diesel, coal, fuel wood and electricity. Human energy was not considered in this study. The energy in MJ used for the production of these materials was computed. Then these materials were compared to obtain the materials with lower energy for a sustainable future.

\section{RESULTS AND DISCUSSION}

The embodied energy value of the selected materials is shown in table 1.The embodied energy value of common materials like OPC, burned clay bricks, etc were found to be high. This shows that these materials consume a large amount of natural resources and also their production leads to the release of large amount of $\mathrm{CO}_{2}$ into the atmosphere, thus contributing towards global warming. Burnt clay bricks consume a large amount of the fertile top soil, which is suitable for agriculture. So it is necessary to use alternative materials to substitute their use. In case of cement, PPC can be used instead of OPC, wherever possible. This also leads to the effective utilization of a waste material i.e., fly ash. Alternative materials for burnt clay bricks include solid and hollow concrete blocks, mud blocks and laterite blocks. Concrete paving tiles, which is nowadays used in pavement construction, landscaping, etc is an energy intensive material and its use is to be reduced. 
Table 1: Embodied Energy of Building Materials

\begin{tabular}{|l|l|}
\hline Material & $\begin{array}{l}\text { Embodied Energy } \\
\text { ( MJ/kg) }\end{array}$ \\
\hline $\begin{array}{l}\text { Solid Concrete Blocks } \\
\text { 40cm x 20cm x15cm }\end{array}$ & 0.286 \\
\hline $\begin{array}{l}\text { Hollow Concrete Blocks } \\
\text { 40cm x 20cm x 15cm }\end{array}$ & 0.374 \\
\hline $\begin{array}{l}\text { Solid Concrete Blocks } \\
\text { 40cm x 20cm x 10cm }\end{array}$ & 0.424 \\
\hline $\begin{array}{l}\text { Hollow Concrete Blocks } \\
\text { 40cm x 20cm x 10cm }\end{array}$ & 0.564 \\
\hline Laterite Blocks & 0.032 \\
\hline Burnt Clay Bricks & 0.813 \\
\hline Mud Blocks & 0.007 \\
\hline RMC M25 & 1.304 \\
\hline Paving Tile & 1.005 \\
\hline 20mm Aggregate & 0.209 \\
\hline 12mm Aggregate & 0.167 \\
\hline 6mm Aggregate & 0.279 \\
\hline Manufactured Sand & 0.105 \\
\hline Quarry Dust & 0.167 \\
\hline Roofing Tile & 1.45 \\
\hline OPC & 7.36 \\
\hline PPC & 4.09 \\
\hline
\end{tabular}

\section{CONCLUSION}

This paper deals with the embodied energy of common and alternative building materials and its comparison. Common building materials are energy intensive and its use has to be reduced. So some alternative building materials were suggested. For a sustainable future, low energy alternative materials should be used.

\section{ACKNOWLEDGMENTS}

I thank god almighty for his blessings. I also extend my heartfelt thanks to my parents for their support. I extend my sincere gratitude to my guides for their guidance throughout the work.

\section{REFERENCES}

[1] Bansal. D, Singh. R and Sawhney. R. L, (2014), "Effect of construction materials on embodied energy and cost of buildings - A case study of residential houses in India up to $60 \mathrm{~m}^{2}$ of plinth area", Energy and Buildings, Vol. 69, pp.260-266.

[2] Bribian. I. Z, Capilla. A. V and Uson. A. A, (2011), "Life cycle assessment of building materials: comparative analysis of energy and environmental impacts and evaluation of the eco- efficiency improvement potential", Building and Environment, Vol. 46, pp. 1133-1140.

[3] Deshmukh. R and More. A, (2014), "Low energy green materials by embodied energy analysis", International Journal of Civil and Structural Engineering Research, Vol.2(1), pp.58-65.
[4] Dixit. M. K, Fernandez-Solis. J. L, Lavy. S and Culp. C. H, (2010), "Identification of parameters for embodied energy measurement: A literature review", Energy and Buildings, Vol.42, pp.1238-1247.

[5] Goggins. J, Keane. T, and Kelly. A, (2010), "The assessment of embodied energy in typical reinforced concrete building structures in Ireland", Energy and Buildings, Vol. 42, pp. 735-744.

[6] Gupta. N. K, Sharma. A. K and Sharma. A, (2013), "Quantifying embodied energy using green building technologies under affordable housing construction", Open Journal of Energy Efficiency, Vol. 2, pp. 171175.

[7] Han. M. Y, Chen. G. Q, Shao. L, Li. J. S, Alsaedi. A, Ahmad. B, Guo. S, Jiang. M. M and Ji. X, (2013), "Embodied energy consumption of building construction engineering: Case study in E-town, Beijing”, Energy and Buildings, Vol.64, pp.62-72.

[8] Henry. A. F, Elambo. N. G, Tah. J. H. M, Fabrice. O. E. N and Blanche. M. M, (2014), "Embodied energy and $\mathrm{CO}_{2}$ analysis of mud-brick and cement block houses", AIMS's Energy, Vol. 2(1), pp. 18-40.

[9] Joshi. K. A and Kambekar. A. R, (2013), "Optimization of energy in public buildings", International Journal of Research in Engineering and Technology, Vol. 84, pp. 423-427.

[10] Kishore. K. N and Chouhan. J. S, (2014), "Embodied energy assessment and comparisons for a residential building using conventional and alternative materials in Indian context", J. Inst. Eng. India Ser. A, Vol. 95(2), pp. 117-127.

[11] Kumar. A, Buddhi. D and Chauhan. D. S, (2012), "Indexing of building materials with embodied, operational energy and environmental sustainability with reference to green buildings", Journal of Pure and Applied Science \& Technology, Vol. 2(1), pp.11-22.

[12] Praseeda. K. I, Reddy. B. V. V and Mani. M, (2015), "Embodied energy assessment of building materials in India using process and input- output analysis", Energy and Buildings, Vol.86, pp. 677-686.

[13] Reddy. B. V. V, (2004), "Sustainable building technologies", Current Science, Vol. 87(7), pp. 899907.

[14] Reddy. B. V. V and Jagadish. K. S, (2003), "Embodied energy of common and alternative building materials and technologies", Energy and Buildings, Vol.35, pp.129-137. 